\title{
Appraisal of Metal Uptake in Wheat Treated with Different Doses of Municipal Solid Waste
}

\author{
FAIZA ANJUM ${ }^{1}$, KAFEEL AHMAD ${ }^{1}$, ZAFAR IQBAL KHAN ${ }^{*}$, SONAINA NAZAR ${ }^{1}$, \\ HUMAYUN BASHIR ${ }^{1,2}$, TASNEEM AHMAD ${ }^{3}$, ASMA ASHFAQ ${ }^{1}$, MUDASRA MUNIR ${ }^{1}$, \\ MUHAMMAD UMER FAROOQ AWAN ${ }^{4}$, KHADIM HUSSAIN ${ }^{5}$, MUHAMMAD NADEEM ${ }^{6}$, \\ JAWAHER ALKAHTANI ${ }^{7}$, MONA S ALWAHIBI ${ }^{7}$, \\ ABEER MUHAMMED ALI ALNASRAWI ${ }^{8}$, RADIQA ARSHAD ${ }^{1}$ \\ ${ }^{1}$ Department of Botany, University of Sargodha, Sargodha, Pakistan \\ ${ }^{2}$ Institute of Molecular Biology and Biotechnology, University of Lahore, Lahore, Pakistan \\ ${ }^{3}$ Pakki Thatti Research and Development Farm, Toba Tek Singh, Pakistan \\ ${ }^{4}$ Governent College University, Lahore, Pakistan \\ ${ }^{5}$ Department of Botany, Govt. MAO College, Lahore, Pakistan \\ ${ }^{6}$ Institute of Food Science and Nutrition, University of Sargodha, Sargodha, Pakistan \\ ${ }^{7}$ Department of Botany and Microbiology, College of Science, King Saud University, Riyadh 11451, Saudi Arabia \\ ${ }^{8}$ Department of Clinical Laboratories, College of Applied Medical Science, University of Kerbala, Iraq
}

\begin{abstract}
The present investigation aimed to assess the metal contents (Fe, $\mathrm{Zn}, \mathrm{Cd}, \mathrm{Co})$ in wheat (Triticum aestivum) crop by selecting variety (Fareed-06) which was grown in the municipal solid waste amended soil. Metal quantification in segregated plant parts of wheat was done with the help of atomic absorption spectrophotometer. Result depicted the range of metals in plant samples to be 4.03 to 7.82 for $\mathrm{Zn}, 2.38$ to 3.06 for Co, 1.7 to 2.91 for Cd and 66.62 to $81.66 \mathrm{mg} / \mathrm{kg}$ for Fe. In wheat grains, the heavy metal concentrations ranged from: 0.79 to 2.03 for $\mathrm{Zn}, 1.21$ to 1.71 for Co, 0.87 to 1.04 for Cd and 10.41 to $21.91 \mathrm{mg} / \mathrm{kg}$ for $\mathrm{Fe}$. The concentration of Cd in grains exceeded the limit set by FAO/WHO. The transfer factor and bioconcentration factor was less than 1 for all metals. The pollution load index and enrichment factor for $C d$ was highest among all metals. Health risk index for $C d$ in all treatments was $>1$ indicating Cd contamination in wheat grains and various health hazards to human. So, the municipal solid waste should be treated properly before its application on agricultural field to reduce the health hazards in human.
\end{abstract}

Keywords: contamination, Triticum aestivum, municipal solid waste, soil, trace metal, daily intake, health risk

\section{Introduction}

Solid waste rich in organic matter plays an important role to fulfill the nutrient requirements of plants. The solid waste affects the crops in different ways such as soil type, weathering conditions, application rate, plant species and application rate; while the applications that do not follow the scientific method affects the plants as well as all living organisms [1]. Amendment of soil with municipal solid waste could enhance the soil structure, since its organic contents can give the essential nutrients that are responsible for the betterment of soil properties [2]. Addition of municipal solid waste to the agricultural land plays significant part for refining soil's physical as well as chemical properties [3]. Various studies have been conducted on municipal solid waste due to its richness in organic matter, which enhances the water holding capacity and mineral status of rhizosphere and also increases crop yield [4]. Therefore, municipal solid waste is used in agricultural land nowadays. Furthermore, soil is natural resource of nutrients whose degradation in arid and semi-arid region affects soil texture and lowers its nutrient content [5]. Therefore, farmer takes different preventive measures by using different waste compounds for improving crop yield [6]. Use of municipal solid waste is an efficient way for improvement of physical and chemical properties of soil [7]. Application of municipal solid waste helps in improving crop yield and also protects against degradation of soil and helps in improvement of soil during drought.

*email:zafar.khan@uos.edu.pk 
Many studies have been conducted on application of municipal solid waste as a soil amendment due to its high uptake of nutrients in agricultural land $[8,9]$. The major limiting factor of sludge containing high concentration of metals like $\mathrm{Cu}, \mathrm{Cd}, \mathrm{Ni}$ and $\mathrm{Zn}$ which could affect the plants and their consumers $[10,11]$. The presence of heavy metals in higher concentration in municipal solid waste is accredited for its adverse effect in the activity of enzyme in the soil [12]. Solid waste can be obtained from the industries and treatment plants during the course of their productions. Many necessary nutrients and organic matter are found commonly in the solid waste in large quantity [13]. Solid waste treatment, if carried out in a systematic way, can increase the yield of many crops manifolds [13, 14]. In term of productivity, addition of amendments, such as Nitrogen or Phosphorus based fertilizers, can catalyze the benefits of the solid waste [14].

The current work was planned and carried out with following objectives: (1) to appraise the influence of solid waste amended soil on metals' transfer from soil to plant (2) to determine bio concentration as well as transfer factor, (3) to estimate the extent to which soil is polluted, (4) to appraise health risk index.

\section{Materials and methods}

\subsection{Study Area}

A potted experimental study was carried out at Department of Botany, University of Sargodha, Pakistan, during 2016-2017, for assessing the heavy metals' quantity in wheat (Triticum aestivum L.) crop variety (Fareed-06) under the influence of municipal solid waste.

\subsection{Cultivation of Plant}

Collection of healthy wheat seeds (Fareed-06) was done during 2016. Four treatments of soil amendment with solid waste were made, mixing the garden soil with municipal solid waste in different concentrations. It included T-1 (100\% garden soil), T-2 (75\% garden soil+ 25\% solid waste), T-3 (50\% garden soil $+50 \%$ solid waste), and T-4 (25\% garden soil $+75 \%$ solid waste). Experiment was done in triplicate. Irrigated with ground water, each experimental pot contained around $3 \mathrm{~kg}$ of soil and 12 seeds. Data related to morphological parameters was collected after 5 months of growth.

Leaf area was measured according to [15] as the following equation

$$
\text { Leaf area }=\text { length } \times \text { width } \times 0.75
$$

Wheat was harvested in April 2017.

\subsection{Sample Collection and Preparation}

The entire plants were collected as samples from each pot, after harvesting them. Samples were left for air drying. Air dried samples were oven-dried at $72^{\circ} \mathrm{C}$. Then grains were removed from the spikelet and panicles. Flour was made by using an electrical grinder for detecting heavy metals. $1 \mathrm{~g}$ of flour from each sample was separated for the digestion purpose, which was done by wet digestion method.

\subsection{Wet Digestion Method}

Dried samples were transferred into little conical flasks and were digested with help of concentrated $\mathrm{HNO}_{3}$ and $\mathrm{H}_{2} \mathrm{O}_{2}$ in the ratio of 1:2 with continuous heating on hot plate. Heat was turned off after disappearance of fumes and $\mathrm{H}_{2} \mathrm{O}_{2}$ was added until the mixture became transparent. Samples digestion process continued till a neutral mixture appeared; finally it was cooled to room temperature. Then these samples were diluted upto $50 \mathrm{~mL}$ in a volumetric glass flask. Whatman filter paper No. 42 was used for filtration of prepared samples. 


\subsection{Soil Digestion}

Top 3-5 cm soil layer was sampled out of every pot. These air-dried samples of soil were then shifted in oven at $65^{\circ} \mathrm{C}$ for $48 \mathrm{~h}$. The soil samples were also digested following the wet digestion procedure.

\subsection{Metals Analysis}

For detection of heavy metals in samples, the digested samples were assessed through Atomic Absorption Spectrophotometry (AA-6300 Shimadzu Japan). Samples were analyzed for the quantification of Cobalt (Co), Cadmium (Cd), Zinc (Zn) and Iron (Fe). Standard mixtures of all four metals were made out of the stock solution to calibrate a curve, in detection procedure.

\subsection{Quality Control}

To confirm consistency and guarantee of the data, for precision of results, international standards were followed by repeated analyses and detection of the trialed. To enhance surety of precision and accuracy, repetition of the analyses was involved in the trial.

\subsection{Statistical Analysis}

\subsubsection{Variance}

SPSS 16 was applied in the statistical studies. ANOVA (on one way basis) was used to analyze the data related to root, shoot, soil and wheat grains.

\subsubsection{Correlation}

Again, by the SPSS package of software (version 16.0), correlation outcomes were obtained. Additionally, Pearson's correlation coefficient was considered, to assess soil-plant interactions, being a bivariant method. For the significant correlation, probability levels of $0.5,0.01$ and 0.001 were used [16].

\subsection{Pollution Load Index (PLI)}

Liu et al. [17] reported that pollution load index (PLI) or contamination factor, for every treatment was worked out according to the given equation:

where:

$$
\mathrm{PLI}=[\mathrm{M}]^{\mathrm{IS}} /[\mathrm{M}]^{\mathrm{RS}}
$$

$[\mathrm{M}]^{\mathrm{IS}}$ and $[\mathrm{M}]^{\mathrm{RS}}$ denotes the metal contents in examined soil sample and reference values for heavy metals occur in soil respectively.

\subsection{Bioconcentration Factor (BCF)}

To evaluate, metals' translocation $(\mathrm{mg} / \mathrm{kg})$ in plant parts from soil, bioconcentration factor (BCF) was calculated as under [18]:

where:

$$
\mathrm{BCF}=[\mathrm{M}]^{\text {Wheat root } /[\mathrm{M}]^{\text {Soil }}}
$$

[M] Wheat root and [M] Soil shows the total metals' content $(\mathrm{mg} / \mathrm{kg})$ in wheat root and wheat soil respectively.

\subsection{Transfer Factor (TF)}

To determine the heavy metals' transfer $(\mathrm{mg} / \mathrm{kg})$ from the root to grains/plants part, transfer factor (TF) was calculated using the following equation [19].

$$
\mathrm{TF}=[\mathrm{M}]^{\text {Wheat grain }} /[\mathrm{M}]^{\text {Wheat root }}
$$


where:

$[\mathrm{M}]^{\text {Wheat root }}$ is the total metal content $(\mathrm{mg} / \mathrm{kg})$ in wheat root

$[\mathrm{M}]^{\text {Wheat grain }}$ is the total metal content $(\mathrm{mg} / \mathrm{kg})$ in wheat grain

\subsection{Enrichment Factor (EF)}

For determination of the extent of soil pollution, an index enrichment factor (EF) was intended in following [20].

$\mathrm{EF}=$ Metal contents in amended soil / Metal contents in control soil

Standard concentrations of metals in soil are given in Table 1.

Table 1. Standard concentration of metals $(\mathrm{mg} / \mathrm{kg})$

in soil and wheat grain

\begin{tabular}{|c|c|c|c|c|}
\hline Metal & Zn & Co & Cd & Fe \\
\hline Soil & $44.19^{\mathrm{a}}$ & $9.1^{\mathrm{a}}$ & $1.49^{\mathrm{a}}$ & $56.90^{\mathrm{b}}$ \\
\hline Grain & $99.4^{\mathrm{c}}$ & $50^{\mathrm{c}}$ & $0.2^{\mathrm{c}}$ & $425.5^{\mathrm{c}}$ \\
\hline \multicolumn{5}{|c}{ Sources: $[27,65,66]$}
\end{tabular}

\subsection{Daily Intake of Metals (DIM)}

Toxic heavy metal enters the human body by different means like oral intake, inhalation or through dermal touch with the metals [21]. Daily intake of metals (DIM) was calculated according to the following equation [22].

$$
\mathrm{DIM}=\mathrm{D}_{\text {food intake }} \times \mathrm{C}_{\text {metal }} / \mathrm{B}_{\text {average weight }}
$$

where:

$\mathrm{D}_{\text {food intake }}$ is the daily intake ( $\mathrm{kg} /$ day) of food crop

$\mathrm{C}_{\text {metal }}$ is the concentration of heavy metal in food crop $(\mathrm{mg} / \mathrm{kg})$, and

$\mathrm{B}_{\text {average weight }}$ is the average body weight $(\mathrm{kg})$.

The average body weight was taken as $55.9 \mathrm{~kg}$ [23] and daily intake of metal in wheat as 0.242 $\mathrm{kg} /$ individual/day [24]. Tolerable daily intake (TDI) refers to the daily amount of metals that has been safe for human consumption. Tolerable daily intake of limit of metals is given in Table 2.

Table 2. Tolerable daily intake (TDI) limit and oral reference dose $\left(\mathrm{R}_{\mathrm{f}} \mathrm{D}\right)$ for metals $(\mathrm{mg} / \mathrm{kg} /$ day $)$

\begin{tabular}{|c|c|c|c|c|}
\hline Metal & $\mathrm{Zn}$ & Co & $\mathrm{Cd}$ & $\mathrm{Fe}$ \\
\hline TDI & $60^{\mathrm{a}}$ & $3 .^{01 \mathrm{~b}}$ & $0.070^{\mathrm{c}}$ & $45^{\mathrm{d}}$ \\
\hline $\mathrm{R}_{\mathrm{f}} \mathrm{D}$ & $0.3^{\mathrm{b}}$ & $0.043^{\mathrm{b}}$ & $0.001^{\mathrm{b}}$ & $0.70^{\mathrm{b}}$ \\
\hline \multicolumn{5}{|c}{ Sources: [57-60] } \\
\hline
\end{tabular}

\subsection{Health Risk Index (HRI)}

Cui et al. [18] described the health risk index (HRI) as the relation of estimated exposure to metal through oral reference dose of food crop.

where,

$$
\mathrm{HRI}=\mathrm{DIM} / \mathrm{R}_{\mathrm{f}} \mathrm{D}
$$

Oral reference dose $\left(\mathrm{R}_{\mathrm{f}} \mathrm{D}\right)$ is the highest tolerable heavy metals oral dose. The oral reference dose values are given in Table 2. 


\section{Results and discussions}

\subsection{Morphological Parameters}

The morphological parameters of plants might be influenced by municipal solid waste, such as length of root, shoot, leaf, width and area of leaf related to wheat crop variety (Fareed-06). The analysis of variance exhibited significant effect $(p<0.05)$ of treatments on length, width and area of leaf while nonsignificant effect $(p>0.05)$ on length of root and shoot in wheat crop variety was detected (Fareed-06) (Table 3).

The maximum values for all of these parameters were noticed in T-3 while the minimum values of these characteristics were noticed in T-1. This might be due to the effect of municipal solid waste. The order of different treatments for different parameters was: T-3>T-2>T-4>T-1 (Table 4). The values of shoot length found in this study were more than the values given by Verma and Sharma [25]. Meagher [26] also predicted the similar results.

Table 3. ANOVA of morphological properties of wheat

\begin{tabular}{|c|c|c|c|c|c|c|}
\hline \multirow{2}{*}{ SOV } & \multirow{2}{*}{ Df } & \multicolumn{5}{|c|}{ Mean square } \\
\cline { 3 - 7 } & & Root length & Shoot length & Leaf length & Leaf width & Leaf area \\
\hline Treatments & 3 & $6.281^{\mathrm{ns}}$ & $95.161^{\mathrm{ns}}$ & $21.15^{* *}$ & $0.162^{* * *}$ & $57.278^{* * *}$ \\
\hline Error & 8 & 11.176 & 35.658 & 4.058 & 0.015 & 4.196 \\
\hline
\end{tabular}

Table 4. Mean values of morphological properties of wheat

\begin{tabular}{|c|c|c|c|c|}
\hline Parameter & T-1 & T-2 & T-3 & T-4 \\
\hline Root length $(\mathrm{cm})$ & $9.83 \pm 1.3$ & $11.13 \pm 0.98$ & $11.26 \pm 1.02$ & $13.33 \pm 1.77$ \\
\hline Shoot length $(\mathrm{cm})$ & $43.9 \pm 0.99$ & $52.93 \pm 1.1$ & $57.33 \pm 0.98$ & $52.73 \pm 1.04$ \\
\hline Leaf length $(\mathrm{cm})$ & $18.83 \pm 1.2$ & $16.83 \pm 0.99$ & $22.6 \pm 1.04$ & $21.73 \pm 1.05$ \\
\hline Leaf width $(\mathrm{cm})$ & $0.4 \pm 0.99$ & $0.76 \pm 1.01$ & $0.93 \pm 1.3$ & $0.83 \pm 0.98$ \\
\hline Leaf area $\left(\mathrm{cm}^{2}\right)$ & $5.89 \pm 1.04$ & $9.59 \pm 0.99$ & $15.78 \pm 0.98$ & $13.55 \pm 1.02$ \\
\hline
\end{tabular}

\subsection{Soil}

Analysis of variance of soil sample values indicated significant impact $(p<0.05)$ on the concentration of metal Zinc and non-significant effect $(p>0.05)$ on the concentration of remaining metals i.e. Co, $\mathrm{Cd}$ and $\mathrm{Fe}$ among all treatments in soil that were employed for growing wheat crop variety (Fareed-06) (Table 5).

Table 5. ANOVA for metal content in soils, roots, shoots and grains of wheat

\begin{tabular}{|c|c|c|c|c|c|}
\hline \multirow{2}{*}{ SOV } & \multirow{2}{*}{$\mathrm{df}$} & \multicolumn{4}{|c|}{ Mean square } \\
\hline & & $\mathrm{Zn}$ & Co & $\mathrm{Cd}$ & $\mathrm{Fe}$ \\
\hline \multicolumn{6}{|c|}{ Soil } \\
\hline Treatments & 3 & $626.882 * *$ & $0.599^{\mathrm{ns}}$ & $0.731^{\mathrm{ns}}$ & $152.589^{\mathrm{ns}}$ \\
\hline Error & 8 & 143.906 & 1.847 & 0.448 & 501.691 \\
\hline \multicolumn{6}{|c|}{ Root } \\
\hline Treatments & 3 & $2.807 * *$ & $0.558^{\mathrm{ns}}$ & $0.898^{\mathrm{ns}}$ & $473.198 * *$ \\
\hline Error & 8 & 0.366 & 2.056 & 1.344 & 87.977 \\
\hline \multicolumn{6}{|c|}{ Shoot } \\
\hline Treatments & 3 & $0.925^{\mathrm{ns}}$ & $0.246^{\mathrm{ns}}$ & $1.836^{\mathrm{ns}}$ & $445.214 * *$ \\
\hline Error & 8 & 0.340 & 1.521 & 2.509 & 107.814 \\
\hline \multicolumn{6}{|c|}{ Grains } \\
\hline Treatments & 3 & $4.352^{\mathrm{ns}}$ & $0.211^{\mathrm{ns}}$ & $0.016^{\mathrm{ns}}$ & $309.450 * * *$ \\
\hline Error & 8 & 16.702 & 0.154 & 0.349 & 39.391 \\
\hline
\end{tabular}

The concentrations of metals under study in soil samples, ranged from 4.03 to $7.82 \mathrm{mg} / \mathrm{kg}$ for $\mathrm{Zn}$, 2.38 to $3.06 \mathrm{mg} / \mathrm{kg}$ for Co, 1.7 to $2.91 \mathrm{mg} / \mathrm{kg}$ for Cd and 66.62 to $81.66 \mathrm{mg} / \mathrm{kg}$ for Fe while in soil samples the trends of metals at T-1, T-2, T-3, and T-4 was: $\mathrm{Fe}>\mathrm{Zn}>\mathrm{Co}>\mathrm{Cd}$ respectively (Figure 1). Among all the treatments the $\mathrm{Cd}$ concentration was lower while $\mathrm{Fe}$ was found to be higher. 


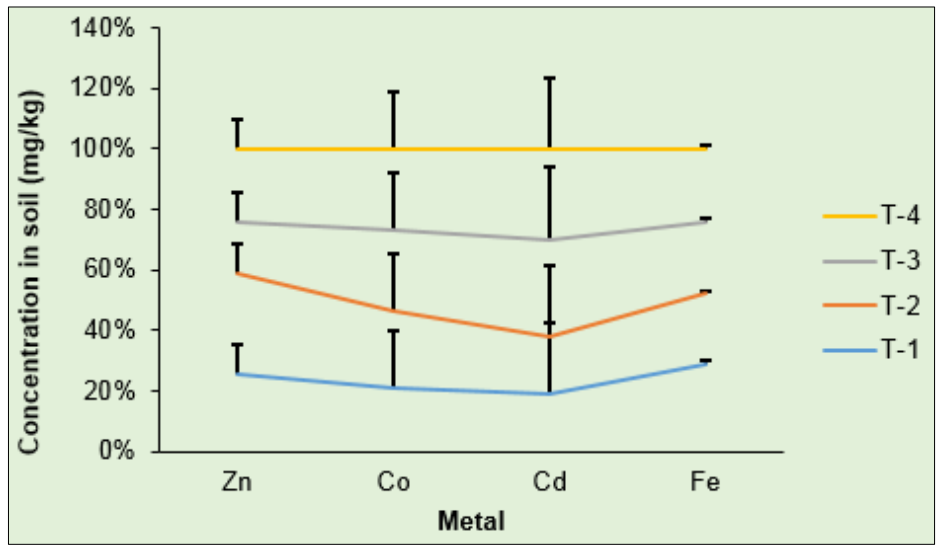

Figure 1. Metal contents (mean values) in soil used for grown wheat

According to FAO/WHO [27] for all heavy metals that are present in the soil, their mean concentration were found to fall inside the acceptable limits / ranges of $\mathrm{Pb}(100 \mathrm{mg} / \mathrm{kg}), \mathrm{Cd}(3 \mathrm{mg} / \mathrm{kg})$, $\mathrm{Ni}(50 \mathrm{mg} / \mathrm{kg}), \mathrm{Fe}(50000 \mathrm{mg} / \mathrm{kg}), \mathrm{Mn}(2000 \mathrm{mg} / \mathrm{kg}), \mathrm{Cu}(100 \mathrm{mg} / \mathrm{kg}), \mathrm{Cr}(50 \mathrm{mg} / \mathrm{kg}), \mathrm{Zn}(300 \mathrm{mg} / \mathrm{kg})$, and $\mathrm{Co}(100 \mathrm{mg} / \mathrm{kg})$. This owes to the higher $\mathrm{pH}$ values of soil. In the present analysis $\mathrm{Zn}$ concentration was lower than the observation of Khan et al. (2007). Co value of our current study was higher as compared to the values of Shar et al. [28]. According to current study, the mean Fe concentration in soil was below than the values of Ekmekyapar et al. [29]. Li et al. [30] determined that the plants absorb Cd in higher amount as compared to other heavy metals and in plants the level of Cd exceeds as much as maximum value therefore it was dangerous to human health. Some metals in plants like $\mathrm{Cd}$ are toxic when present in greater amount. They disturb the enzyme activities by substituting the metalo-enzymes into the metal ions and cause various physiological impairments in plants [31]. The high quantity of heavy metals in soil has been reported to hinder plant growth, uptake of nutrients and metabolic processes [32].

\subsection{Root}

ANOVA exhibited a significant effect i.e. $p<0.05$ of all treatments on $\mathrm{Fe}$ and $\mathrm{Zn}$ contents while a non-significant $(p>0.05)$ effect was visible in $\mathrm{Co}$ and $\mathrm{Cd}$ concentrations in root of wheat crop variety (Fareed-06) (Table 5).

In the root of wheat, the trend of heavy metals at T-1, T-2 and T-4 was: $\mathrm{Fe}>\mathrm{Zn}>\mathrm{Co}>\mathrm{Cd}$ at T-3 was: $\mathrm{Fe}>\mathrm{Zn}>\mathrm{Cd}>\mathrm{Co}$ while the metals concentrations ranged from: 3.03 to $6.03 \mathrm{mg} / \mathrm{kg}$ for $\mathrm{Zn}, 2.01$ to 2.73 $\mathrm{mg} / \mathrm{kg}$ for Co, 1.41 to $2.45 \mathrm{mg} / \mathrm{kg}$ for Cd and 20.08 to $47.78 \mathrm{mg} / \mathrm{kg}$ for Fe respectively (Figure 2). Fe gave highest concentration while $\mathrm{Co}$ and $\mathrm{Cd}$ gave the lowest concentrations in all used treatments.

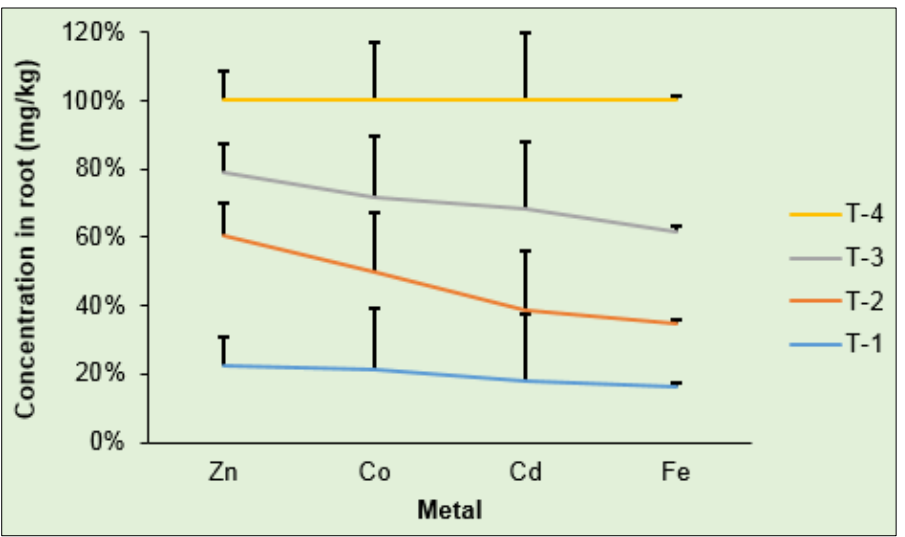

Figure 2. Metal contents (mean values) in root of wheat 
In roots, high portion of heavy metals amassed due to the $\mathrm{Zn}$ polluted soil [33]. Recent results showed higher concentration of $\mathrm{Cd}$ and $\mathrm{Zn}$ than the findings of Al-Othman et al. [34]. Zinc was an essential element for the production and growth of plants as well as humans, aiding in the growth, development of brain, healing of wound and formation of bone. In all samples $\mathrm{Zn}$ concentration was noticed to be lower than the acceptable level in crops $(99.40 \mathrm{mg} / \mathrm{kg})$.

\subsection{Shoot}

In shoot, ANOVA established a significant effect $(p<0.05)$ for all treatments on the Fe contents while non-significant effect $(p>0.05)$ on the concentrations of remaining metals including; Zinc, Cobalt and Cadmium in wheat shoot of crop variety (Fareed-06) (Table 5). The concentrations of the metals under study, in shoot of wheat, ranges as Zn: 1.03 to $2.84 \mathrm{mg} / \mathrm{kg}$, Co: 1.56 to $1.99 \mathrm{mg} / \mathrm{kg}$, Cd: 1.04 to 2.02 $\mathrm{mg} / \mathrm{kg}$, and Fe: 11.4 to $36.79 \mathrm{mg} / \mathrm{kg}$ while the order of the metals at T-1 was: $\mathrm{Fe}>\mathrm{Co}>\mathrm{Cd}>\mathrm{Zn}$, at T-2 and T-4 was: $\mathrm{Fe}>\mathrm{Zn}>\mathrm{Co}>\mathrm{Cd}$ and at $\mathrm{T}-3$ was: $\mathrm{Fe}>\mathrm{Cd}>\mathrm{Zn}>\mathrm{Co}$ respectively (Figure 3 ). The $\mathrm{Zn}$, Co and $\mathrm{Cd}$ indicated the lower concentrations and Fe showed highest concentration in shoot of wheat.

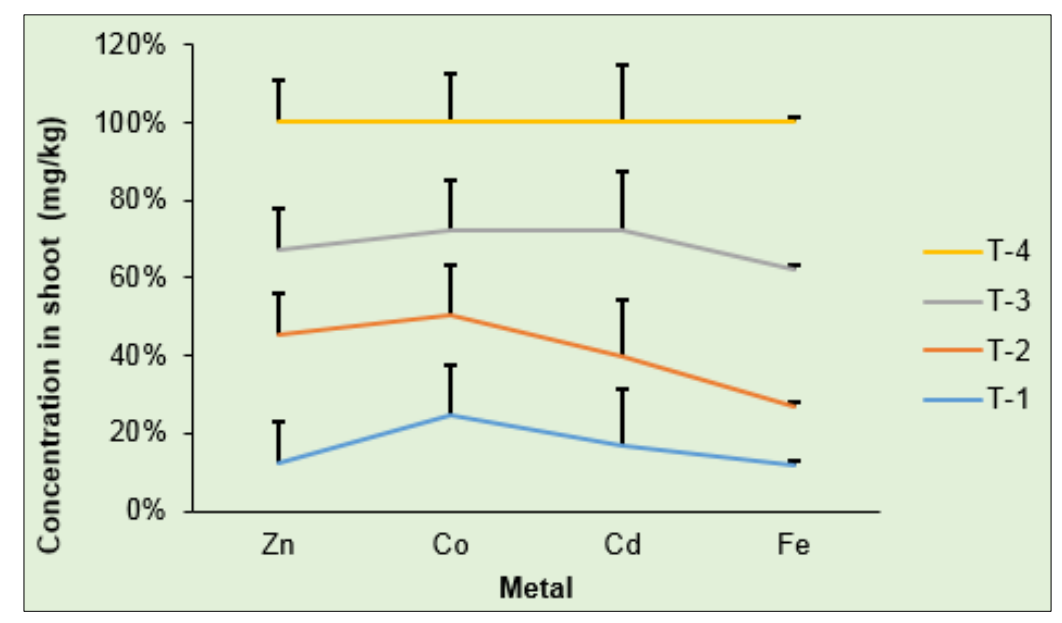

Figure 3. Metal contents (mean values) in shoot of wheat

The mean concentration of zinc in shoot samples was lower in present investigation than the results of Al-Othman et al. [34]. Cadmium concentration was lower than the readings of Meng et al. [35]. The noticed values of $\mathrm{Zn}$ were fall within in the permissible limits as reported by the WHO/FAO [36].

The basic source of $\mathrm{Cd}$ was tobacco smoke that causes diseases in humans as it contains considerable amount of $\mathrm{Cd}$ that enters in the human body, causes infection in the lungs as well as in the gastrointestinal tract $[37,38]$. The presence of $\mathrm{Cd}$ in plants causes reduction in the growth of shoot as well as in the root, in germination of seed and decreases the nutrient content in plants [39-41].

\subsection{Grains}

ANOVA in grains indicated significant effect $(p<0.05)$ of all treatments on the metal Fe contents while a non-significant effect $(p>0.05)$ on metals Zn, Cobalt \& Cadmium of the wheat variety (Fareed06) (Table 5).

Heavy metals concentration in wheat grains ranged from 1.21-1.71, 0.79-2.03, 0.87-1.04 and 10.41$21.91 \mathrm{mg} / \mathrm{kg}$ for $\mathrm{Co}, \mathrm{Zn}, \mathrm{Cd}$ and $\mathrm{Fe}$ respectively. At $\mathrm{T}-1$ and $\mathrm{T}-2$, the sequence of heavy metal concentration in wheat variety (Fareed-06) was: $\mathrm{Fe}>\mathrm{Co}>\mathrm{Cd}>\mathrm{Zn}$ and at T-3 and T-4 was: $\mathrm{Fe}>\mathrm{Zn}>\mathrm{Co}>\mathrm{Cd}$ (Figure 4). Iron exhibited the highest concentration while $\mathrm{Zn}$ and $\mathrm{Cd}$ exhibited lower values among all treatments. 


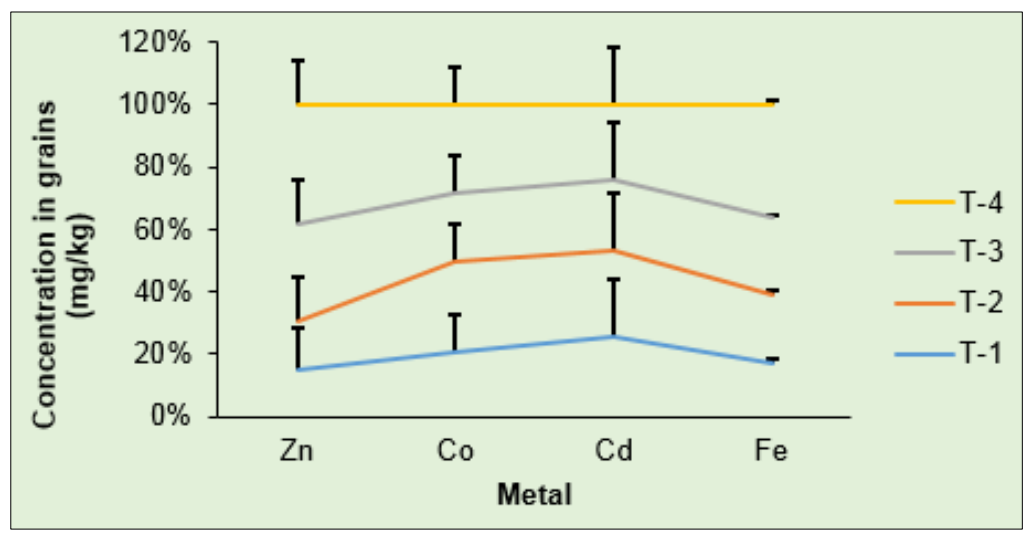

Figure 4. Mean concentrations of metals in grains of wheat

According to FAO/WHO [27] the mean metals' concentration present in wheat grains were found to be fall within the acceptable limit excluding $\mathrm{Cd}$. $\mathrm{Zn}$ concentration of the present analysis was lower and $\mathrm{Cd}$ concentration was higher than the observation of Jākobsone et al. [42]. It means that the wheat was polluted by the $\mathrm{Cd}$. The poisoning of $\mathrm{Cd}$ in humans causes several diseases such as lungs cancer, anemia, renal damage, bone disorder, cardiovascular diseases [43].

In present investigations, the $\mathrm{Zn}$ concentration in the grains was noticed lower than the tolerable limit (99. $\mathrm{mg} / \mathrm{kg}$ ) as reported by $\mathrm{FAO} / \mathrm{WHO}$ [27]. Our current readings were quite similar than the observations of Verma et al. (2015) [44]. Kalagbor et al. [45] suggested that the over production of RBC's (red blood cells) occurs when there is excessive consumption of cobalt. As compared to recent study, higher standards of Co were studied by Shad et al. [46].

According to recent readings the cobalt concentration in grains was found to be lower than the tolerable limit i.e. $50 \mathrm{mg} / \mathrm{kg}$ while concentration of Fe was fall within the acceptable limit as informed by FAO/WHO [27]. In human body iron is essential for the transport of electron because it plays a significant part in oxygen transportation [47].

\subsection{Correlation}

In soil-root, $\mathrm{Zn}$ and $\mathrm{Cd}$ exhibited positive and significant correlation, Co gave positive and nonsignificant correlation and $\mathrm{Fe}$ showed negative correlation. In root-shoot, all metals ( $\mathrm{Zn}, \mathrm{Co}, \mathrm{Cd}$ and $\mathrm{Fe}$ ) exhibited positive and non-significant correlation. In shoot-grain, only $\mathrm{Cd}$ metal displayed negative correlation while $\mathrm{Zn}$, Co and Fe showed positive and non-significant correlation (Table 6). A positive correlation in most heavy metals like in $\mathrm{Co}, \mathrm{Cd}$ and Fe showed that these were coming from the same water source. Non-significant correlation between the heavy metals and wheat grains was reported by Ekmekyapar et al. [29]. Positive and significant correlation of Fe was also reported by Khan et al. [47]. Lago-Vila et al. [48] studied the correlation of Co in plants.

Table 6. Correlation between soil-root, root-shoot and shoot-grain metal concentrations

\begin{tabular}{|c|c|c|c|}
\hline Metal & Soil-Root & Root-Shoot & Shoot-Grains \\
\hline $\mathrm{Zn}$ & $0.982^{*}$ & $0.481^{\text {ns }}$ & $0.391^{\text {ns }}$ \\
\hline $\mathrm{Co}$ & $0.363^{\text {ns }}$ & $0.815^{\text {ns }}$ & $0.730^{\text {ns }}$ \\
\hline $\mathrm{Cd}$ & $0.952^{*}$ & $0.882^{\text {ns }}$ & -0.776 \\
\hline $\mathrm{Fe}$ & -0.529 & $0.931^{\text {ns }}$ & $0.834^{\text {ns }}$ \\
\hline *: Correlation is significant at 0.05 level, ns: non-significant correlation
\end{tabular}

\subsection{Bioconcentration Factor}

The order of $\mathrm{BCF}$ at $\mathrm{T}-1$ was: $\mathrm{Co}>\mathrm{Cd}>\mathrm{Zn}>\mathrm{Fe}$, at $\mathrm{T}-2$ was: $\mathrm{Co}>\mathrm{Cd}>\mathrm{Zn}>\mathrm{Fe}$, at $\mathrm{T}-3$ was: $\mathrm{Cd}>\mathrm{Zn}>\mathrm{Co}>\mathrm{Fe}$ and at $\mathrm{T}-4$ was: $\mathrm{Cd}>\mathrm{Co}>\mathrm{Fe}>\mathrm{Zn}$. Bioconcentration factor was examined to check out the exchange of heavy metals from soil to all edible parts of the plants (Table 7). Bioconcentration factor 
values ranged from 0.586879 to $0.7711 \mathrm{mg} / \mathrm{kg}$ for $\mathrm{Zn}, 0.666667$ to $0.97153 \mathrm{mg} / \mathrm{kg}$ for Co, 0.786942 to $0.94152 \mathrm{mg} / \mathrm{kg}$ for $\mathrm{Cd}$ and 0.245898 to $0.702234 \mathrm{mg} / \mathrm{kg}$ for Fe respectively. The values of BCF for Co and $\mathrm{Cd}$ were highest while the values of $\mathrm{BCF}$ for Fe and $\mathrm{Zn}$ were lowest in all treatments.

Bioconcentration factor in humans was considered as the necessary factor to evaluate the exposure via food chain. In recent study $\mathrm{Fe}$ and $\mathrm{Zn}$ shown the lower mobility from soil to plant due to their lower $\mathrm{BCF}$ value but for Co and Cd the highest BCF values were found which showed that they have higher mobility from soil to plant. It was determined by Lokeshwari and Chandrappa [49] that the Cd binds less strongly to the soil due to its high mobility as compared to other heavy metals. Khan et al. [47] discussed the high $\mathrm{BCF}$ values of $\mathrm{Fe}$ and $\mathrm{Zn}$ as compared to present findings. Bioconcentration factor values of $\mathrm{Co}$ were also studied by Lago-Vila et al. [48].

\subsection{Transfer Factor}

Determination of heavy metals transferring from soil to the entire plant parts was done by using transfer factor. For T-1 and T-2 the TF sequence was: $\mathrm{Cd}>\mathrm{Co}>\mathrm{Fe}>\mathrm{Zn}$, while at T-3 and T-4 it was: $\mathrm{Co}>\mathrm{Zn}>\mathrm{Fe}>\mathrm{Cd}$ whereas the TF standards ranged from 0.135987 to $0.613293 \mathrm{mg} / \mathrm{kg}$ for $\mathrm{Zn}, 0.60199$ to $0.642157 \mathrm{mg} / \mathrm{kg} \mathrm{Co}, 0.379913$ to $0.702128 \mathrm{mg} / \mathrm{kg}$ for Cd and 0.427737 to $0.562392 \mathrm{mg} / \mathrm{kg}$ for Fe respectively. In observed samples, TF standards of Co was found mostly higher while Fe showed mostly lowest standards for TF (Table 7).

Transfer factor of heavy metals was affected by different factors such as their concentrations in soil, their chemical forms and the uptake capability of plants. That's why the transfer factor values of heavy metals were different in soil and plants. The highest value of $\mathrm{Cd}$ was due to the high accumulation of heavy metals by plants and vegetables [35]. The transfer results of heavy metals from soil to plants were constant than that of Beijing, China [17]. Meng et al. [35] also discussed the transfer of metal $\mathrm{Zn}$ in vegetables was lower than current results.

Table 7. Bioconcentration factor and transfer

\begin{tabular}{|c|c|c|c|c|}
\multicolumn{5}{|c|}{ factor for all metals of wheat } \\
\begin{tabular}{|c|c|c|c|c|}
\hline Treatment & Zn & Co & Cd & Fe \\
\hline \multicolumn{5}{|c|}{ BCF } \\
\hline T-1 & 0.592346 & 0.844538 & 0.829412 & 0.245898 \\
\hline T-2 & 0.7711 & 0.97153 & 0.94152 & 0.346443 \\
\hline T-3 & 0.751861 & 0.666667 & 0.786942 & 0.506133 \\
\hline T-4 & 0.586879 & 0.906355 & 0.910781 & 0.702234 \\
\hline \multicolumn{5}{|c|}{ TF } \\
\hline T-1 & 0.22191 & 0.60199 & 0.702128 & 0.518426 \\
\hline T-2 & 0.135987 & 0.626374 & 0.645963 & 0.562392 \\
\hline T-3 & 0.537954 & 0.642157 & 0.379913 & 0.427737 \\
\hline T-4 & 0.613293 & 0.616236 & 0.383673 & 0.45856 \\
\hline
\end{tabular}
\end{tabular}

\subsection{Pollution Load Index}

Pollution effects were determined by the pollution load index. In the observed samples PLI ranged between 0.091197 to $0.176963 \mathrm{mg} / \mathrm{kg}$ for $\mathrm{Zn}, 0.261538$ to $0.336264 \mathrm{mg} / \mathrm{kg}$ for Co, 1.14094 to 1.95302 $\mathrm{mg} / \mathrm{kg}$ for Cd and 1.170826 to $1.435149 \mathrm{mg} / \mathrm{kg}$ for Fe respectively, while the sequence for PLI at T-1 was: $\mathrm{Fe}>\mathrm{Cd}>\mathrm{Co}>\mathrm{Zn}$, at $\mathrm{T}-2$ was: $\mathrm{Fe}>\mathrm{Cd}>\mathrm{Co}>\mathrm{Zn}$, at $\mathrm{T}-3$ was: $\mathrm{Cd}>\mathrm{Fe}>\mathrm{Co}>\mathrm{Zn}$ and at $\mathrm{T}-4$ was: $\mathrm{Cd}>\mathrm{Fe}>\mathrm{Co}>\mathrm{Zn}$. Fe showed highest PLI while Co and Zn showed lowest PLI in all treatments (Table 8).

Pollution load index was determined to estimate the contamination in soil and it was differentiated by the greater and lower PLI. The values of PLI greater than 1 indicated the contaminated soil and those lower than 1 showed the uncontaminated soil [50].

In present investigations, PLI values of $\mathrm{Fe}$ and $\mathrm{Cd}$ was greater than 1 it means that these metals were highly contaminated and have high environmental risk. Pollution load index values were high due to the following factors: by human activities, agricultural runoff and industrial activities [51-53]. Khan et al. [47] discussed the PLI values of $\mathrm{Fe}$ and $\mathrm{Zn}$ as related to current results. 


\subsection{Enrichment Factor}

The trends of EF for each metal at T-1 and T-2 was: $\mathrm{Cd}>\mathrm{Co}>\mathrm{Zn}>\mathrm{Fe}$, at $\mathrm{T}-3$ and $\mathrm{T}-4$ was: $\mathrm{Cd}>\mathrm{Zn}>\mathrm{Co}>\mathrm{Fe}$. EF values in all treatments reached from 0.046617 to $0.179813 \mathrm{mg} / \mathrm{kg}$ for $\mathrm{Zn}, 0.077915$ to $0.110754 \mathrm{mg} / \mathrm{kg}$ for $\mathrm{Co}, 2.227322$ to $4.530999 \mathrm{mg} / \mathrm{kg}$ for Cd, 0.017047 to $0.043062 \mathrm{mg} / \mathrm{kg}$ for Fe. In all treatments, EF values were found higher for Cd metal and lowest for Fe (Table 8). Enrichment factor in the soil explains the abundance of heavy metals compared to their standard level [54]. The higher EF values of Cd showed that it has less preservation in soil while low EF values of Fe showed that it has high preservation in soil and less mobility. Sherif et al. [55] has been suggested the higher EF values of Co while similar EF values of $\mathrm{Cd}$ as related to present investigation.

Table 8. Pollution load index and enrichment factor of wheat

\begin{tabular}{|c|c|c|c|c|}
\hline Treatment & Zn & Co & Cd & Fe \\
\hline \multicolumn{5}{|c|}{ PLI } \\
\hline T-1 & 0.136004 & 0.261538 & 114.094 & 1.435 .149 \\
\hline T-2 & 0.176963 & 0.308791 & 1.147 .651 & 1.170 .826 \\
\hline T-3 & 0.091197 & 0.336264 & 195.302 & 1.189 .279 \\
\hline T-4 & 0.127631 & 0.328571 & 1.805 .369 & 1.195 .782 \\
\hline \multicolumn{5}{|c|}{ EF } \\
\hline T-1 & 0.058437 & 0.092529 & 4.338 .536 & 0.017047 \\
\hline T-2 & 0.046617 & 0.110754 & 4.530 .999 & 0.026054 \\
\hline T-3 & 0.179813 & 0.077915 & 2.227 .322 & 0.02895 \\
\hline T-4 & 0.160013 & 0.101652 & 2.603 .347 & 0.043062 \\
\hline
\end{tabular}

\subsection{Daily Intake of Metals}

DIM patterns in all heavy metals at $\mathrm{T}-1$ and $\mathrm{T}-2$ was: $\mathrm{Fe}>\mathrm{Co}>\mathrm{Cd}>\mathrm{Zn}$, at $\mathrm{T}-3$ and $\mathrm{T}-4$ was: $\mathrm{Fe}>\mathrm{Zn}>\mathrm{Co}>\mathrm{Cd}$. The ranges of DIM values were 0.00342 to $0.008788 \mathrm{mg} / \mathrm{kg}$ for $\mathrm{Zn}, 0.005238$ to $0.007403 \mathrm{mg} / \mathrm{kg}$ for Co, 0.003766 to $0.004502 \mathrm{mg} / \mathrm{kg}$ for Cd, and 0.045067 to $0.094852 \mathrm{mg} / \mathrm{kg}$ for Fe. In current samples, Fe showed highest DIM vales whereas Cd mostly showed the lowest DIM values among all treatments (Table 9).

In current results, the DIM values were below than the tolerably daily intakes as recommended by the WHO [56], USEPA [57], Food and Nutritional Board [58], WHO/FAO [60], USEPA [60]. In all treatments the DIM values were lower than 1 which means that it has no risk by the consumption of wheat. The crops that were grown in the waste water irrigated soil possess no risk for the consumer [61]. Wang et al. [62] reported the bigger DIM values of Cadmium and lower DIM values of $\mathrm{Zn}$ as compares to present study.

\subsection{Health Risk Index}

HRI values ranged from 0.0114 to $0.029293 \mathrm{mg} / \mathrm{kg}$ for $\mathrm{Zn}, 0.121814$ to $0.172163 \mathrm{mg} / \mathrm{kg}$ for Co, 3.766 to $4.502 \mathrm{mg} / \mathrm{kg}$ for $\mathrm{Cd}$ and 0.064381 to $0.135503 \mathrm{mg} / \mathrm{kg}$ for Fe. Health risk index in all treatments (T-1, T-2, T-3 and T-4) was indicated in the following order: $\mathrm{Cd}>\mathrm{Co}>\mathrm{Fe}>\mathrm{Zn}$. It means that in all samples $\mathrm{Cd}$ HRI values were highest and $\mathrm{Zn}$ displayed lowest HRI values (Table 9).

In many countries, food chains were used to estimate the health risk where the major source of irrigation was waste water. In human body, heavy metals intake was done through different paths like water, air, food and soil etc. [63]. Health risk index values of Cd elevate the maximum permissible limit in vegetables as well as in cereals such as wheat (Triticum aestivum) [64]. The local inhabitants of an area close to a smelter in Nanning, China were found to have no risk by wheat consumption containing heavy metals in it [18].

Table 9. Daily intake of metal and health risk index via intake of wheat

\begin{tabular}{|l|l|l|l|l|}
\hline Treatment & Zn & Co & Cd & Fe \\
\hline DIM & 0.00342 & 0.005238 & 0.004286 & 0.045067 \\
\hline T-1
\end{tabular}




\section{Conclusions}

\begin{tabular}{|l|l|l|l|l|}
\hline T-2 & 0.00355 & 0.007403 & 0.004502 & 0.056192 \\
\hline T-3 & 0.007057 & 0.005671 & 0.003766 & 0.063422 \\
\hline T-4 & 0.008788 & 0.00723 & 0.004069 & 0.094852 \\
\hline HRI & 0.0114 & 0.121814 & 4.286 & 0.064381 \\
\hline T-1 & 0.011833 & 0.172163 & 4.502 & 0.080274 \\
\hline T-2 & 0.023523 & 0.131884 & 3.766 & 0.090603 \\
\hline T-3 & 0.029293 & 0.16814 & 4.069 & 0.135503 \\
\hline T-4
\end{tabular}

Municipal solid waste utilized as soil amending agent for enhancing mineral status of soil also brings toxic metals which contaminate the soil as well as food crops which are grown in such soil, consequently posing various health risks to consumers. In present work, values of $\mathrm{Fe}, \mathrm{Zn}$ and $\mathrm{Co}$ in soil and all part of wheat plant was found within the permissible limit given by FAO/WHO while Cd concentration exceeded the permissible limit. The bio concentration factor for all metals was less than 1 . The pollution load index and enrichment factor for Cd was highest among all metals. The value of HRI for Cd was greater than 1 showed that wheat grains were contaminated with cadmium and pose various health hazards to human. So, the municipal solid waste should be treated properly before its application on agricultural field to reduce the health hazards in human.

Acknowledgment. The authors extend their appreciation to the Researchers Supporting Project Number (RSP-2020/173) King Saud University, Riyadh, Saudi Arabia.

\section{References}

1.RABIE, M. H., NEGM A. Y., ELEIWA, M. E., ABDEL M. F., SABOUR., Influence of two sewage sludge sources on Faba bean and Sorghum plants growth and elements uptake. Egypt. J. Soil Sci. 37(4) $1997,425-435$.

2.CHU, L.M., WONG. M. H., Heavy metal contents of vegetable crops treated with refuse compost and sewage sludge. Plant Soil. 103(2),1987, 191-197.

3.SORT, X., ALCANIZ, J. M., Effect of sewage sludge amendment on soil aggregation. Land Degradation and Development, Land Degrad. Dev. 10(1), 1999, 3-12.

4.LOBO, T.F., H. GRASSI- FILHO, L.T. BULL AND L.L.Q. MOREIRA., Management of sewage sludge and mineral nitrogen in soil fertility over time. Semina: Ciênc. Agrár. 34(6), 2013, 2705-2725.

5.NEFFAR, S., CHENCHOUNI, H., BEDDIAR A., REDJEL, N., Rehabilitation of degraded rangeland in dry lands by prickly pear (Opuntia ficus-indica L.) plantations: Effect on soil and spontaneous vegetation. Ecol. Balkanika., 5: 2014, 63-76.

6.OUSTANI, M., HALILAT, M. T., CHENCHOUNI, H., Effect of organic fertilizers on the yield and nutriments uptake of potato under saline conditions of Saharan regions. Emir. J. Food Agric. 27(1), 2015, 106-120.

7.SHAHEEN, S. M., SHAMS, M. S., IBRAHIM, S. M., ELBEHIRY, F. A., ANTONIADIS, V., HOODA, P.S., Stabilization of sewage sludge by using various by-products: effects on soil properties, biomass production, and bioavailability of copper and zinc. Water Air Soil Pollut. 2014, 225.

8.ORMAN, S., OK H., KAPLAN, M., Application of sewage sludge for growing alfalfa, its effects on the macro micronutrient concentration, heavy metal accumulation, and translocation. Ekoloji 23(90), 2014, 10-19.

9.KHAN, ZI., MALIK S., AHMAD K., WAJID K., MUNIR M., UGULU I., DOGAN Y., Efficacy of transfer of heavy metals in wheat grown in municipal solid waste amended soil. Catrina. 20 (1), 2020, 31-38

10.BARRIQUELO, M., MARINES, J., SILVA M., LENZI. E., Lead behavior in soil treated with contaminated sewage sludge and cultivated with maize. J. Braz Arch Biol Technol. 46(4), 2003, 499505.

11.BASLAR S., KULA, I., DOGAN Y., YILDIZ D, A. Y. G., A study of trace element contents in plants growing at Honaz Dagi-Denizli, Turkey. Ekoloji. 18(72), 2009, 1-7. 
12.GIGLIOTTI, G., GIUSQUIANI P., BUSINELLI, D., A long-term chemical and infrared spectroscopy study on a soil amended with municipal sewage sludge. Agronomie 21(2), 2001, 169-178. 13.SILVA, J., RESCK, D., SHARMA, R., Alternative for agronomic biosolids produced in the Federal District. I - Effect on corn production and the addition of heavy metals in an oxisol in the Cerrado. $R$. Bras. Ci. Solo. 26, 2002, 487-495.

14.BJUHR, J., Trace metals in soils irrigated with waste water in a periurban area downstream Hanoi City, Vietnam. SLU, Dept. of Soil Sciences, Uppsala. 2007

15.QUARRIE, S. A., JONES, H. G., Effects of abscisic acid and water stress on development and morphology of wheat. Journal of Experimental Botany. 28(102), 1977, 192-203.

16.STEEL, R. G. D., TORRIE, J. H., Principles and Procedures of Statistics: A Biometrical Approach, Mc Graw-Hill New York. 1996.

17.LIU, W. H., ZHAO, J. Z., OUYANG, Z. Y., SÖDERLUND LIU G. H., Impacts of sewage irrigation on heavy metal distribution and contamination in Beijing, China. Environ Int. 31(6), 2005, 805-812.

18.CUI, Y. J., ZHU, Y. G., ZHAI, R. H., D.Y. CHEN, Y. Z., HUANG, Y., QUI AND, J. Z. LIANG., Transfer of metals from near a smelter in Nanning, China. Environ Int. 30: 782-791.

19.MIRECKI, N., AGIC, R., SUNIC, L., MILENKOVIC., ILIC. Z. S., Transfer factor as indicator of heavy metals content in plants. Fresenius Environmental Bulletin, Fresen Environ Bull, 24(11), 2015, $4212-4219$.

20.AL-HWAITI, M., AL-KHASHMAN, O., Health risk assessment of heavy metals contamination in tomato and green pepper plants grown in soils amended with phosphogypsum waste materials. Environ Geochem Health. 37(2), 2014, 287-304.

21.SHAHID, M., DUMAT, C., POURRUT, B., ABBAS, G., SHAHID, N., PINELLI, E., Role of metal speciation in lead-induced oxidative stress to Vicia faba roots. Russ J Plant Physiol. 62(4), 2015, 448454.

22.KHAN, S., FAROOQ, R., SHAHBAZ, S., KHAN M. A., SADIQUE S., Health risk assessment of heavy metals for population via consumption of vegetables. World Appl. Sci. J. 6, 2009,1602-1606.

23.WANG, X., HUAN, G. W., TIAN, H.G., DONG, S.R., YIN H.G., CAO, X. H., Investigation on dietary of urban residents in Tianjin from 2000-2004. China. J. Publ. Health, 23, 2007, 1245.

24.WANG, X., SATO, T., XING B., TAO, S., Health risks of heavy metals to the general public in Tianjin, China via consumption of vegetables and fish. Sci Total Environ. 350(1-3), 2005, 28-37.

25.VERMA, L., SHARMA, J., Effect of dairy and textile waste water on growth of plant wheat. Rasayan J. Chem. 5(3), 2012, 351-355.

26.MEAGHER, R. B., Phytoremediation of toxic elemental and organic pollutants. Curr Opin Plant Biol. 3, 2000.153-162.

27.FAO/WHO (Food and Agriculture Organization of the United Nations/World Health Organization). Codex Alimentarius Commission. Food Additive and Contaminants. Joint FAO/WHO Food Standards Programme, ALINORM 01/12a, 2001, 1-289.

28.SHAR, G. Q., KAZI, T. G., JAKHRANI, M. A., SAHITO, S. R., MEMON, M. A., Determination of seven heavy metals, cadmium, cobalt, chromium, nickel, lead, copper and manganese in wheat flour samples by flame atomic absorption spectrometry. J Chem Soc Pakistan 24(4), 2002, 265-268.

29.EKMEKYAPAR, F., SABUDAK, T., SEREN, G., Assessment of heavy metal contamination in soil and wheat (Triticum aestivum L.) plant around the Corlu-Cerkezkoy Highway in Thrace Region. Global Nest J 14(4), 2012, 496-504.

30.LI, G. C., LIN, H. T., LAI, C. S., Uptake of heavy metals by plants in Taiwan. In: Biogeochemistry of trace elements. D. C. Adriano, Z.S. Chen, and Y.S. Yang (editors). Science and Technology Letters, Northwood, U.K. pp. 1994, 153-160.

31.AGARWAL, S. K., Studies on the effect of the auto exhaust emission on the Mitragyna patriflora, Ajmeer, India: Maharshi Dayanand Saraswati University; Master Thesis. pp.1. 1999.

32.BAISBERG-PAHLSSON, A. M., Toxicity of heavy metals ( $\mathrm{Zn}, \mathrm{Cu}, \mathrm{Cd}, \mathrm{Pb}$ ) to vascular plants. Water Air Soil Pollut 47(3-4), 1989, 287-319. 
33.STALIKAS, C. D., MANTALOVAS, A., PILIDIS, G.A., Multi element concentrations in vegetable species grown in two typical agricultural areas of Greece. Sci Total Environ. 206, 1997, 17-24.

34.AL-OTHMAN, Z. A., ALI, R., AL-OTHMAN, A. M., ALI J., HABILA, M. A., Assessment of toxic metals in wheat crops grown on selected soils, irrigated by different water sources. Arabi J Chem 9: 2016, 1555-1563.

35.MENG, W., WANG, Z., HU, B., WANG, Z., LI AND H., GOODMAN, R.C., Heavy metals in soil and plants after long-term sewage irrigation at Tianjin China: A case study assessment. Agric Water Manag. 171: 2016, 153-161.

36.***WHO/FAO (World Health Organization/Food and Agriculture Organization of the United Nations) and National Safety Limits. Framework for Developing National Food Safety Emergency Response Plan. 2010,1-24.

37.MING-HO, Y., Environmental toxicology: Biological and health effects of pollutants, Chap. 12, 2nd Edition, CRC Press LLC, Boca Raton, USA. 2005.

38.FIGUEROA, E., Are more restrictive food cadmium standards justifiable health safety measures or opportunistic barriers to trade? An answer from economics and public health. Sci Total Environ. 389(1), 2008, 1-9.

39.AHMAD, I., AKHTAR, M. J., ZAHIR Z. A., JAMIL, A., Effect of cadmium on seed germination and seedling growth of four wheat (Triticum aestivum L.) cultivars. Pak. J Bot. 44(5), 2012, 1569-1574. 40.YOURTCHI, M. S., BAYAT, H. R., Effect of cadmium toxicity on growth, cadmium accumulation and macronutrient content of durum wheat (Dena CV.). Int J Agri Crop Sci. 6(15), 2013, 1099-1103.

41.UGUlU, I, M., UNVER, C., DOGAN, Y., Determination and comparison of heavy metal accumulation level of Ficus carica bark and leaf samples in Artvin, Turkey. Oxid Commun., 39(1-2), 2016, 765-775.

42.JĀKOBSONE, I., KANTĀNE, I., ZUTE, S., JANSONE, I., BARTKEVIČS, V., Macro-elements and trace elements in cereal grains cultivated in Latvia. Proceedings of the Latvian Academy of Sciences. Sect B Nat Exact Appl Sci. 69(4), 2015, 152-157.

43.AHMAD, K., NAWAZ K., KHAN Z. I., NADEEM M., WAJID, K., Effect of diverse regimes of irrigation on metals accumulation in wheat crop: an assessment-dire need of the day. Fresenius Environ Bull. 27(2), 2018, 846-855.

44.VERMA, S., YADAV, S., YADAV, S. K., KADYAN, P. S., SINGH I., SINGH, D., Heavy metals in wheat grains of Haryana (India) and their health implications. J Chem Pharm Res. 7(10), 2015, 342351.

45.KALAGBOR, I., DIRI, E., 2014. Evaluation of heavy metals in orange, pineapple, avocado pear and pawpaw from a form in Kaani, Rivers State Nigeria. International Research Journal of Public and Environmental Health, Int. Res. J. Public Environ. Health 1(4): 87-94.

46.SHAD, H.A., Z.I. KHAN, K. AHMAD, RIZWAN, Y., TAHIR, H. M. Human health hazards caused by heavy metals accumulation in wheat variety (Sehar-2006) irrigated with domestic sewage water. Biologia (Pakistan), 60(1), 2014, 99-102.

47.KHAN, Z.I., AHMAD, K., ASHRAF, M., YASMEEN, S., ASHFAQ, A., SHER, M., Metal accumulation in a potential winter vegetable mustard (Brassica campestris L.) irrigated with different types of waters in Punjab, Pakistan. Pak J Bot. 48(2), 2016, 535-541.

48.LAGO-VILA, M., ARENAS-LAGO, D., RODRIGUEZ-SEIJO, A., ANDRADE-COUCE M. L., VEGA, F. A., Cobalt, chromium and nickel contents in soils and plants from a serpentinite quarry. Solid Earth, 6: 2015, 323-335.

49.LOKESHWARI, H., CHANDRAPPA, G. T., Impact of heavy metal contamination of Bellandur Lake on soil and cultivated vegetation. Curr Sci. 91(5), 2006, 622-627.

50.HARIKUMAR, P.S., NASIR, U. P., MUJEEBU RAHMAN M. P., Distribution of heavy metals in the core sediments of a tropical wetland system. Int J Environ Sci Tech. 6(2), 2009, 225-232. 
51.MAIZ, I., ARAMBARRI, I., GARCIA R., MILLAN., Evaluation of heavy metal availability in polluted soils by two sequential extraction procedures using factor analysis. Environ Poll. 110(1), 2000, 3-9.

52.USMAN, S. O. A., AYODELE, J. T., Bioaccumulation of four heavy metals in leaves of Calotropis procera. Journal of Chemical Society Nigeria, 27: 2002, 26-27.

53.UWAH, E.I., NDAHI N. P., OGUGBUAJA V. O., Study of the levels of some agricultural pollutants in soils, and water leaf (Talinum triangulare) obtained in Maiduguri, Nigeria. J Appl Sci Environ Sanit. 4(2), 2009, 71-78.

54.HERNANDEZ, L., PROBST, A., PROBST, J. L., ULRICH, E. Heavy metal distribution in some French forest soils: evidence for atmospheric contamination. Sci Total Environ 312(1-3):2003, 195-219. 55.SHERIF, A. E. A., EL-KHOLY, M. M., SALEM, T. M., Risk assessment of trace elements toxicity through edible plants from irrigation canal at Giza Governate, Egypt. Iran. E. Energy Environ. 6(1), 2015, 47-55.

56.***WHO (WORLD HEALTH ORGANIZATION)., Quality Directive of Potable Water, Geneva, Second Ed, pp. 197. pp. 1. 1994.

57.***USEPA (UNITED STATES ENVIRONMENTAL PROTECTION AGENCY)., Region 9, Preliminary Remediation Goals. Office of Research and Development, Washington, DC, USA.pp.1. 2002.

58.***FOOD AND NUTRITIONAL BOARD., Recommended Intake for Individuals, Dietary Reference Intakes [DRIs]. National Academy of Sciences, Washington, DC, USA. pp.1. 2004.

59.***WHO/FAO (WORLD HEALTH ORGANIZATION/FOOD AND AGRICULTURE ORGANIZATION OF THE UNITED NATIONS)., Joint WHO/FAO Food Standards Program Code Alimentarius Commission 13th Session, Report of the Thirty-Eight Session of the Codex Committee on Food Hygiene, Houston, Texas, USA, ALINORM 07/30/13. pp. 1. 2007.

60.***USEPA (UNITED STATES ENVIRONMENTAL PROTECTION AGENCY)., Integrated Risk Information System.pp.1. 2010.

61.RADWAN, M. A, SALAMA A. K., Market basket survey for some heavy metals in Egyptian fruits and vegetables. Food Chem. Toxicol 44: 2006, 1273-1278.

62.WANG, Z., ZENG, X., GENG, M., CHEN, C., CAI, J., YU, X., HOU Y., ZHANG, H., health risks of heavy metals uptake by crops grown in a sewage irrigation area in China. Pol J Environ Stu 24(3), 2015, 1379-1386.

63.CAUSSY, D., GOCHFELD, M., GURZAU, E., NEAGU C., RUEDEL, H., Lessons from case studies of metals: Investigation exposure, bioavailability, and risk. Ecotoxicol Environ Saf 56(1), 2003, 45-51.

64.IKEDA, M., Z. W., ZHANG, S., SHIMBO, T., WATANABE, H., NAKATSUKA, C. S. MOON., MATSUDA-INOGUCHI N., HIGASHIKAWA, K., Urban population exposure to lead and cadmium in east and south-east Asia. Sci Total Environ 249(1-3), 2000, 373-84.

65.SINGH, A., SHARMA, R. K., AGRAWAL, M., Risk assessment of heavy metal toxicity through contaminated vegetables from wastewater irrigated area of Varanasi. Trop Ecol 51: 2010, 375-87.

66.DOSUMU, O. O., SALAM N. A., OGUNTOY, N. S., Trace metals bioaccumulation by some Nigerian vegetables. Centrepoint 13(1), 2005, 23-32

Manuscript received: 13.10 .2020 